\title{
CYCLOSPORIN A REDUCES AIRWAY MUCUS SECRETION AND MUCOCILIARY CLEARANCE IN RATS
}

\author{
Rogerio Pazetti, Paulo Manuel Pego-Fernandes, Otavio Tavares Ranzani, Edwin \\ Roger Parra, Geraldo Lorenzi-Filho, Fabio B. Jatene
}

Pazetti R, Pego-Fernandes PM, Ranzani OT, Parra ER, Lorenzi-Filho G, Jatene FB. Cyclosporine A reduces airway mucus secretion and mucociliary clearance in rats. Clinics. 2007:62(3):345-52.

PURPOSE: To assay the effects of cyclosporin A on mucus secretion from goblet cells and on mucociliary transport in situ in rats.

METHODS: Twenty-one male Wistar rats were assigned to 3 groups: control $(\mathrm{n}=5)$, saline $(\mathrm{n}=8)$, and cyclosporin A $(\mathrm{n}=8)$. After 30 days of drug therapy, the rats were killed, and the lungs were removed from the thoracic cavity. Mucus samples were collected, and the transport rate was evaluated in vitro using a bullfrog palate model. Mucociliary transport was timed in situ by direct view of particles trapped on the mucus moving across the respiratory tract. Finally, the amount of stored mucins in the goblet cells of the respiratory epithelium was measured.

RESULTS: Drug dosage measurements showed that cyclosporine blood concentration at the moment the rats were killed was $1246.57 \pm 563.88 \mathrm{ng} / \mathrm{mL}$. The in vitro transport rate was significantly lower $(P<.001)$ in the cyclosporin A-treated group. Also, the in-situ mucociliary transport rate was decreased in all cyclosporin A-treated animals when compared to the saline group $(P=$ .02). Mucus quantity measurements showed a significant decrease on both acid $(P=.01)$ and neutral $(P=.02)$ mucus production from goblet cells in the animals submitted to cyclosporin A therapy. The correlation between the percentage of total mucus and in vitro transport rate was positive and significant $(r=0.706, P<.001)$, as was the correlation between the percentage of total mucus and the in situ mucociliary transport rate $(r=0.688, P=.001)$.

CONCLUSION: This study shows that cyclosporin A plays an important role in the impairment of the mucociliary clearance in rats by reducing both acid and neutral mucus production from goblet cells and causing a decrease in the mucociliary transport velocity.

KEYWORDS: Cyclosporine. Mucociliary clearance. Goblet cell. Mucin.

\section{INTRODUCTION}

Mucociliary clearance is the principal nonspecific defense mechanism of the airways. In the upper airways, particles and other inhaled materials are entrapped in mucus and transported by ciliary motion, termed mucociliary transport, from the lungs. Under normal circumstances, efficient mucociliary transport is the result of the coordination of 3 airway epi-

Thoracic Surgery Service, Hospital das Clinicas, Faculty of Medicine, University of Sao PauloSao Paulo/ SP, Brazil.

Email: rogeriopazetti@yahoo.com.br

Received for publication on December 1, 2006.

Accepted for publication on February 23, 2007. thelial cell functions: quantitative and qualitative mucus secretion, ciliary beating, and fluid transport. ${ }^{1}$

Respiratory mucus secretion is an important element in mucociliary transport. This mucus is composed of $1 \%$ by weight of salts and other dialysable components; $0.5 \%$ to $1 \%$ free protein; a similar proportion of carbohydraterich glycoproteins, also called mucins; and $95 \%$ or more of water. ${ }^{2}$

The chemical composition of the respiratory mucus glycoproteins is suspected to influence the formation of the molecular network of mucus, thereby altering its rheological properties. Pharmacological interference in mucociliary transport is caused by a new class of drugs used 
for immunosuppressant therapy, but the mechanism for this mucociliary effect has not been established. ${ }^{3}$ Cyclosporin A (CsA) is one of the most important immunosuppressants used in lung transplantation. ${ }^{4-6}$

Although the molecular events have not yet been completely defined, some studies indicate that CsA blocks the initial stages of lymphocyte activation, ${ }^{7,8}$ inhibiting the production of interleukin-2 and other lymphokins..$^{9,10}$ Theoretically, the mechanism of action of CsA includes an influence on cytoplasmatic calcium, which is an essential component for normal cellular function. ${ }^{11}$ Some authors have reported a direct correlation between $\mathrm{CsA}$-induced cytotoxicity and changes in mitochondrial enzyme activity. ${ }^{12,13}$ Cyclosporin $\mathrm{A}$ has also the ability to interact with receptors within the nucleus to inhibit genetic transcription of proteins secreted by fibroblasts, endothelial cells, macrophages, and monocytes. ${ }^{14}$ Moreover, CsA has many side effects, such as nephrotoxicity, hepatotoxicity, gum hypertrophy, hypertension, and a high incidence of lymphoma. The side effects are usually dose-dependent, and are reversed following dose reduction. ${ }^{15-17}$

Because mucociliary clearance is inhibited in patients receiving immunosuppressants such as CsA, we also considered it relevant to assess whether CsA acts on the goblet cell activity causing impairment either on quantity or quality of the respiratory mucus.

\section{METHODS}

Twenty-one male Wistar rats $(300 \pm 25 \mathrm{~g})$ were assigned to 3 groups as follows: control $(n=5)$, intact animals; saline $(n=8)$, animals that received saline solution $(0.9 \%$ $\mathrm{NaCl}$, Baxter) subcutaneously for a 30 days period; and CsA $(n=8)$, animals that received Cyclosporin A (SANDIMMUN ${ }^{\circledR}, 50 \mathrm{mg} / \mathrm{mL}$, Novartis, Switzerland) at a dose of $10 \mathrm{mg} / \mathrm{kg} /$ day, subcutaneously, for 30 days.

The animals were maintained according to the "Guide for the Care and Use of Laboratory Animals," ${ }^{18}$ and the protocol was approved by our institutional Ethics Committee.

After 30 days of drug therapy, the rats were anesthetized with pentobarbital (50 mg/kg, intraperitoneally) and killed by exsanguination, according to the "Report of the American Veterinary Medicine Association Panel on Euthanasia." 19

In the CsA group, before exsanguination, blood samples were collected from abdominal aorta, and drug dosage measurements were made by fluorescence polarization immunoassay FPIA with the TDxFLx ${ }^{\circledR}$ system.

After euthanasia, the lungs were removed from the thoracic cavity, and an incision was performed along the tra- cheobronchial tree. Mucus samples were collected by placing a soft-bristled brush against the pulmonary airway and removing the brush once it was covered with sufficient mucus for analysis. ${ }^{20}$

The in vitro transport rate was evaluated by using a bullfrog (Rana catesbeiana) palate model. Briefly, the transport velocity of the mucus sample placed on a frog palate was determined with the aid of a stereomicroscope fitted with a micrometer scale. Three to five measurements of the transport rate of the rat mucus samples were taken to minimize measurement variability, and the average transport rate of each one was normalized to the transport rate for collected endogenous frog mucus; the results were expressed as relative speed (rat/frog). ${ }^{21,22}$

After mucus sample collection, the ventral wall from tracheobronchial tree was removed to expose the respiratory epithelium. Then, the tissue was placed and analyzed in a light microscope (Olympus, BX50, Tokyo, Japan) fitted with a micrometer scale, and in situ mucociliary transport was timed by direct view of particles trapped on mucus moving across the respiratory tract.

Finally, to measure the amount of stored mucins in the respiratory epithelium, serial sections $(3 \mu \mathrm{m}$ thick) from main stem bronchi were cut with a microtome and stained with periodic acid-Schiff (PAS) and alcian blue (AB) sequences to demonstrate neutral and acidic mucosubstances, respectively. ${ }^{23}$

All slides were blinded, and an Image-Pro Plus 4.1 for Windows (MediaCybernetics, Silver Spring, MD), running on a microcomputer connected to a digital camera (JVC TK-C1380 color video camera; Victor Company of Japan, Yokohama, Japan) coupled to an optical microscope (Leica DMR; Leica Microsystems, Bensheim, Germany) was used for the measurements.

Ten fields per slide were evaluated at a final magnification $\mathrm{x} 400$. In each field, we quantified the mucus percentage per respiratory epithelium area as follows:

mucus $=\frac{\text { mucus area } \times 100}{\text { epithelium area }} \rightarrow[\%]$

Data were analyzed using a Statistic Package for Social Sciences for Windows (SPSS 10.0 version) program. Results are expressed as mean \pm standard deviation (SD), and a $P$ value less than .05 was considered significant. We used a 1-way ANOVA test to verify the interference and interaction of the analyzed factors. Comparisons between groups were performed using Bonferroni post-tests. To evaluate the correlation between the variables, Pearson's correlation coefficient and the linear regression model were used. $^{24}$ 


\section{RESULTS}

Drug dosage measurements showed that the blood concentration of CsA at the moment the rats were killed was $1,246.57 \pm 563.88 \mathrm{ng} / \mathrm{mL}(\mathrm{M} \pm \mathrm{SD})$.

The in vitro transport rate was significantly less $(P<.001)$ in the CsA group than in the saline group (Figure 1). Also, the in situ mucociliary transport rate was decreased in the CsA group compared to the saline group $(P=.02)$ (Figure 2).

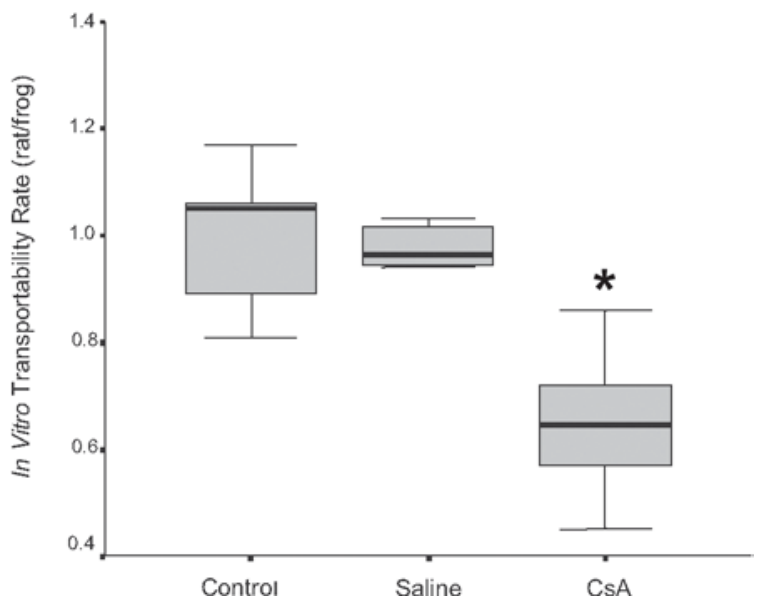

Figure 1 - In vitro transport rate from rats treated with saline or cyclosporin A for 30 days. There was significant difference between groups $(P<.001)$.

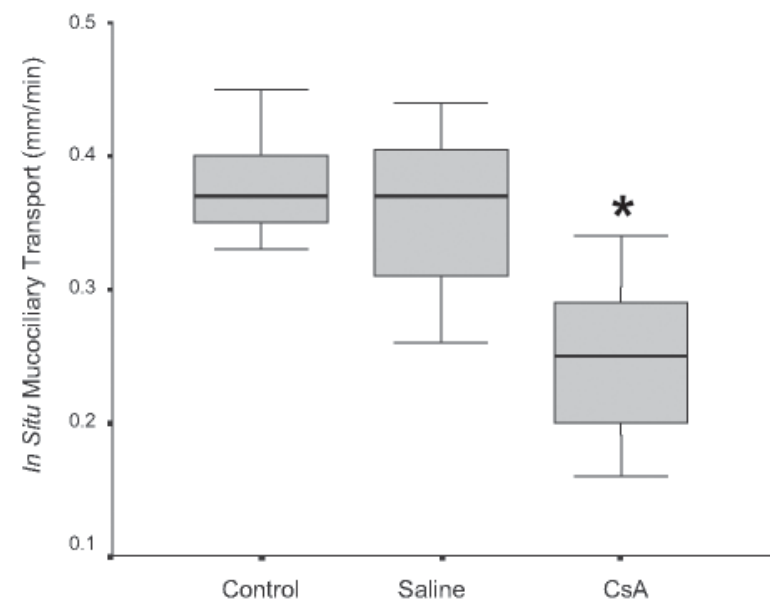

Figure 2 - In situ mucociliary transport rate of rats treated with saline or cyclosporin A for 30 days. There was significant difference between groups $(P=.02)$.

Mucus quantity measurement results showed a significant decrease $(P=.002)$ of total mucus from goblet cells in the animals submitted to CsA therapy (Figure 3). When compared to the saline group, the CsA group presented lower amounts of acid and neutral mucus, and this difference was statistically significant $(P<.05)$. In pair-wise comparisons between the saline and CoA groups, significant differences were found for acid mucus $(P=.01)$ and neutral mucus $(P=.02)$, respectively.

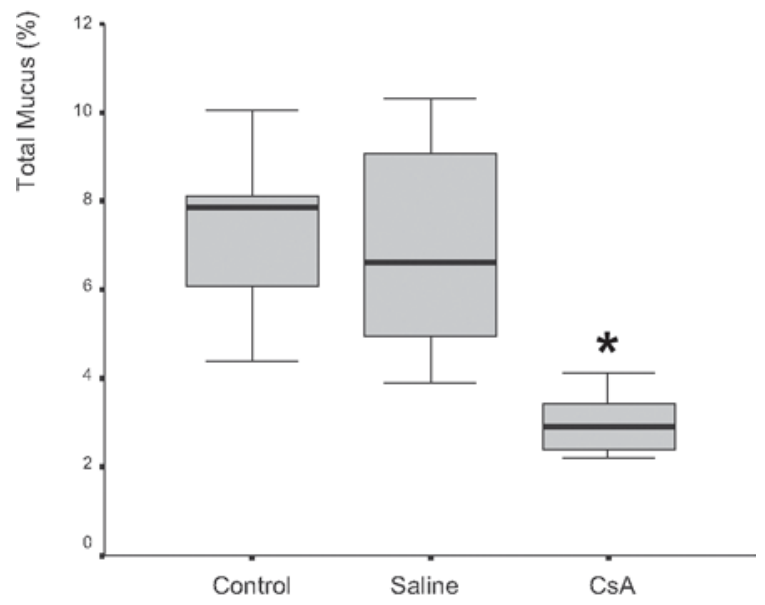

Figure 3 - Percentage of mucus in respiratory epithelium from rats treated with saline or cyclosporin A for 30 days. There was significant difference between groups $(P=.002)$.

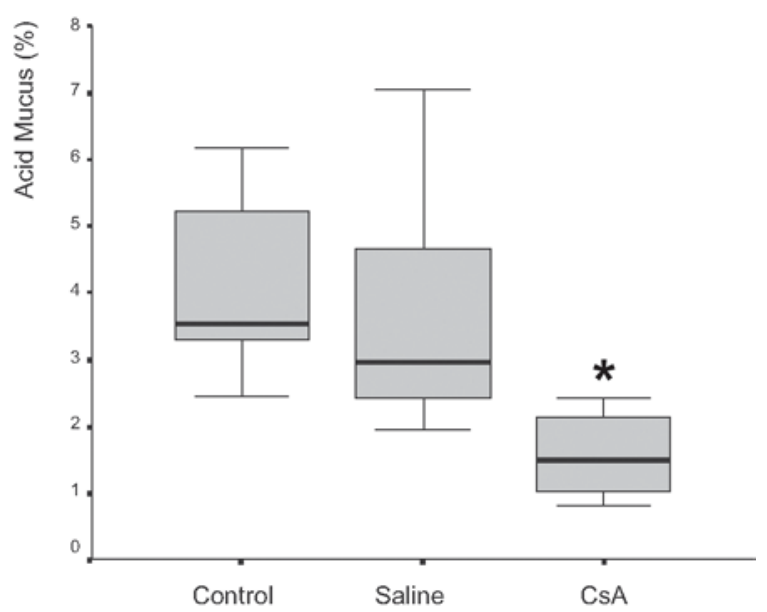

Figure 4 - Percentage of acid mucus in respiratory epithelium from rats treated with saline or cyclosporin A for 30 days. There was significant difference between groups $(P=.01)$.

The correlation between the percentage of total mucus and the in-vitro transport rate was positive and significant $(r=0.706, P<.001)$ (Figure 6). Similar results were found in the correlation of the percentage of total mucus in the respiratory epithelium and the in-situ mucociliary transport rate $(r=0.688, P=.001)$ (Figure 7).

Figures 8 and 9 are representative illustrations of the amount of acid and neutral mucus in respiratory epithelium from the saline and CsA groups, respectively.

\section{DISCUSSION}

Many studies have been done with the aim of better understanding the various factors involved with CsA therapy, such as its structure, administration route, toxicity, immunosuppressant effects, and its relationship with other immunosuppressant agents. ${ }^{25}$ 


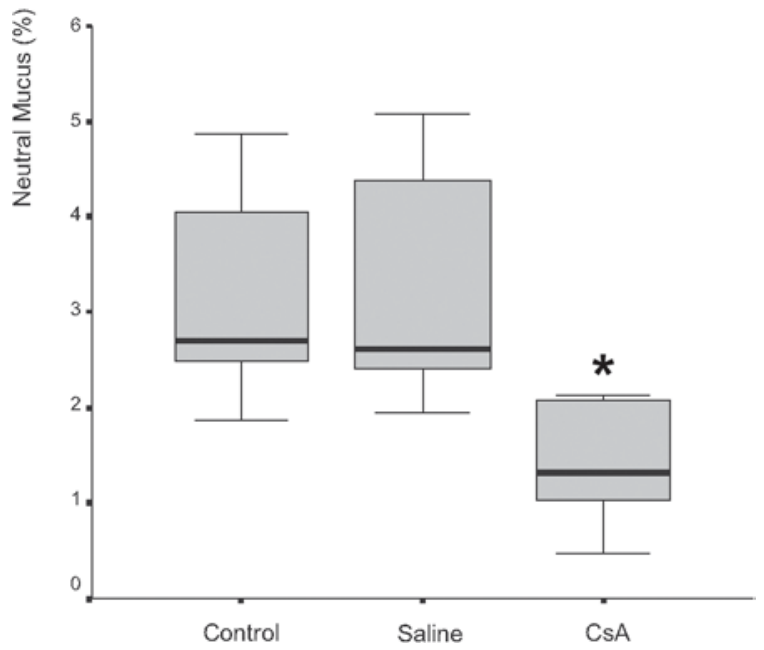

Figure 5 - Percentage of neutral mucus in respiratory epithelium from rats treated with saline or cyclosporin A for 30 days. There was significant difference between groups $(P=.02)$.

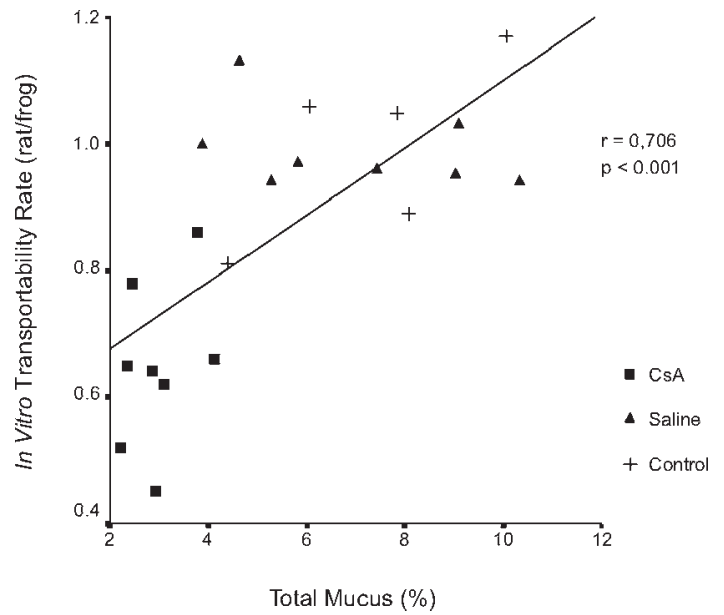

Figure 6 - Relationship between in vitro transport rate and percentage of total mucus in respiratory epithelium from rats treated with saline or cyclosporin A for 30 days. There was significant difference between groups $(r=0.706 ; P<.001)$.

Due to its lipophilic nature, CsA is highly dissolved in organs and quickly delivered into tissues and plasmatic stores. ${ }^{26,27}$ In the blood, $90 \%$ is linked to plasma proteins, and $10 \%$ to granulocytes and lymphocytes. ${ }^{28,29}$ More than $70 \%$ of the administered CsA is processed by the liver and excreted together with the bile; up to $10 \%$ of its metabolites can be eliminated through the renal route. ${ }^{30}$ In humans, absorption of the drug occurs through the small intestine, and its half-life is around 6 to 9 hours. ${ }^{31}$ In human transplantation, CsA is frequently administered orally and intravenously. However, in the rat experimental model, the intramuscular and subcutaneous routes are preferable.

The dosage of CsA is variable according to whether patients are undergoing organ transplant procedures, or are different responses in the rejection process. ${ }^{25}$ In this study, we tested a dosage that is commonly used in humans im-

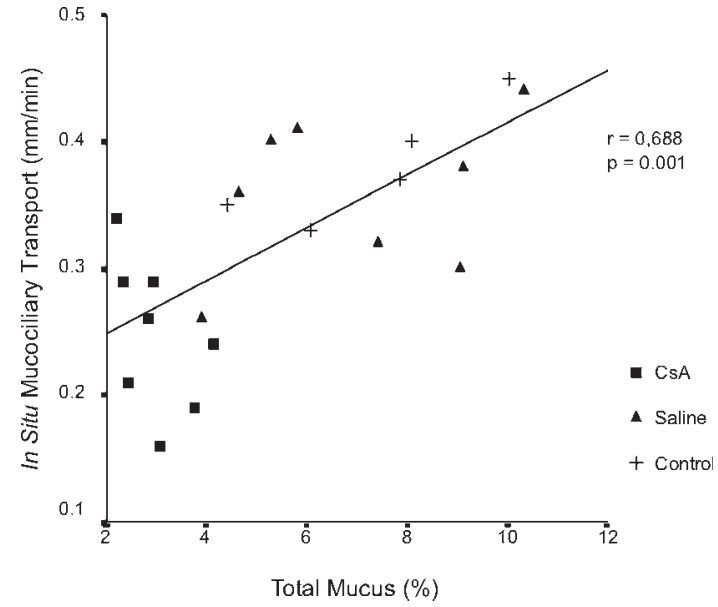

Figure 7 - Relationship between in situ mucociliary transport and percentage of total mucus in respiratory epithelium from rats treated with saline or cyclosporin A for 30 days. There was significant difference between groups $(r=0.688 ; P=.001)$.

mediately after transplantation. We administered CsA daily (10 $\mathrm{mg} / \mathrm{kg}$ of body weight, subcutaneously), and the mean serum levels we found $(1,246 \mathrm{ng} / \mathrm{mL})$ were similar to those of others who tested the pharmacokinetics of the drug in rats. ${ }^{25}$ Many studies have reported that this is an effective and nontoxic dose that it is also well tolerated by rats, producing a constant serum concentration. ${ }^{32}$

To assess the influence of CsA on the transportability of the mucus samples, we used an in-vitro model of mucus depleted frog palate, since the bullfrog's palate is lined with a pseudostratified epithelium, similar to that found in human conductive airways. ${ }^{21}$ Rubin and co-workers ${ }^{22}$ suggested that bullfrog mucus has viscoelastic properties that are similar to those of normal mammalian respiratory mucus. This technique has been widely used as a means of defining the inherent transportability of mucus, independent of systemic ciliary function. Respiratory mucus must have ideal physical properties (viscosity and elasticity) to allow cilia penetration, to receive their transmitted energy and to provide effective mucus transport along the ciliated epithelium. ${ }^{33}$ Due to the cross-linking of glycoproteins, the rheological behavior of mucus is described as viscoelastic, having characteristics of both a liquid and a solid. ${ }^{34}$

The relative proportions of elasticity and viscosity are important in describing how a material such as mucus behaves when it is subjected to external forces. The ratio of viscosity to elasticity is also an important determinant of mucociliary clearance. Increasing viscosity at constant elasticity in a model system caused a pronounced decrease in the mucociliary transport rate. ${ }^{35}$ Although this phenomenon has not been observed for intact mucus from healthy animals, it has been seen in pathological human material. ${ }^{36}$

In this study, we observed that mucus samples collected 

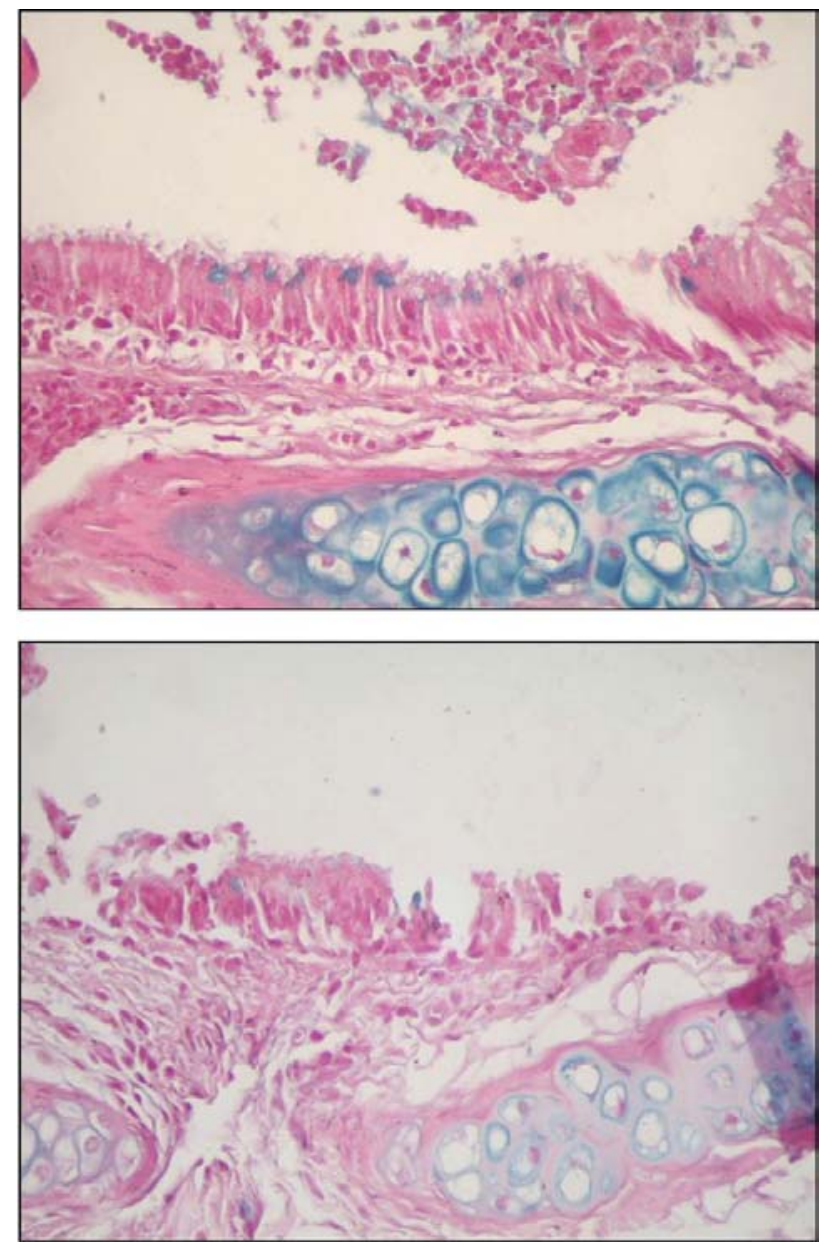

Figure 8 - Quantity of acid mucus in respiratory epithelium from saline (A) and cyclosporin A (B) groups.

from the CsA group showed a significantly decreased transport rate when compared with samples collected from the saline group. Moreover, the analysis of the in-situ mucociliary clearance rate also showed significant impairment of the transport speed in the CsA group. These results show that CsA changed the quality of mucus by altering either its viscosity or elasticity, or both.

The perfect function of mucociliary transport depends on an interaction among various factors, such as an intact ciliated epithelium with synchronized ciliary beating, an adequate amount of mucus with ideal viscoelastic properties, and the adequate composition and size of the periciliary fluid layer, which is determined mainly by the quality and quantity of mucous glycoproteins or mucins present in the mucus. ${ }^{37}$

The respiratory tract mucus has characteristics that allow its interaction with ciliated cells, such as an adequate depth of the periciliary layer (sol phase) and an ideal mechanical behavior. If the periciliary layer is too thick, cilia will not be able to reach the gel phase, and therefore will not be able to
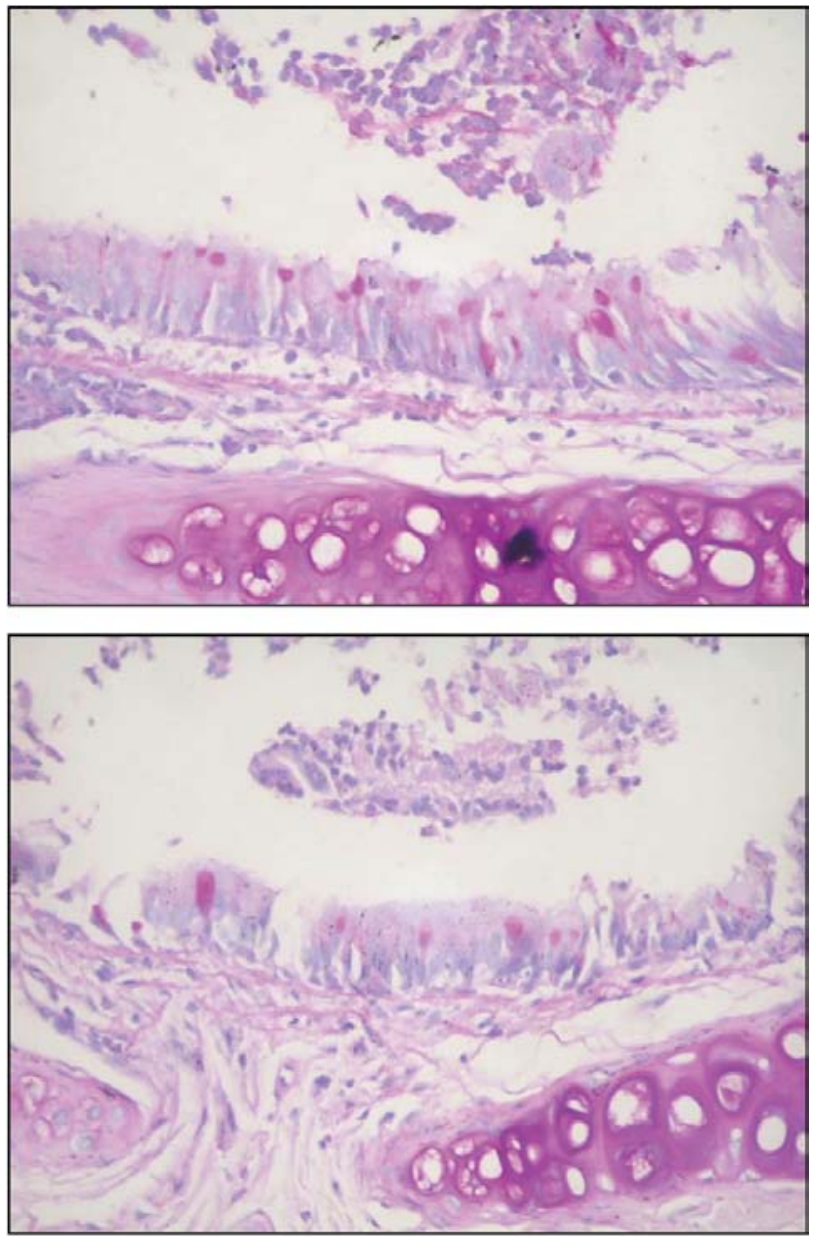

Figure 9 - Quantity of neutral mucus in respiratory epithelium from saline (A) and cyclosporin A (B) groups.

push it. Conversely, when the periciliary layer is thin, cilia will be permanently in contact with the gel phase, which in turn will hinder the recovery movement of cilia. ${ }^{38}$ In both situations, there is some degree of impairment of the mucus transport rate, which may result in mucostasis, a characteristic shared by several airway diseases. ${ }^{39}$

The concept that alterations in mucus volume impact mucus hydration, and thus the rheology of mucus resulting in an increase in susceptibility to infection in cystic fibrosis airways, continues to gain credence..$^{40} \mathrm{~A}$ marked decrease in the airway surface liquid volume in cystic fibrosis bronchial explants in-vitro reflects the abnormal ion transport properties of cystic fibrosis airway epithelia in vivo. ${ }^{41}$ Similar behavior as well as increased amounts of mucus and altered mucus transport and mucus adhesion to airway surfaces is observed in-vivo in mice that overexpress the subunit of the epithelial sodium channel, $\mathrm{ENaC}{ }^{42}$

The sol phase composition of the mucus is controlled by a complex mechanism of absorption and secretion of liquids from several ionic channels of the apical membrane 
of epithelial cells. In addition, the ionic channels probably regulate the hydration degree of the gel phase, thus modulating its rheological properties. ${ }^{34}$

To assess whether CsA also affects the amount of mucus secretion from goblet cells, we quantified both acid and neutral mucus in respiratory epithelium. Airway mucins are thought to be derived from periodic-acid-Schiff (PAS)-positive secretory granules ("mucous" granules) found in 2 different cell types in the airway: goblet cells of the surface epithelium and mucous cells of the submucosal glands. ${ }^{43}$ Since airway mucins are a mixture of mucins secreted from the 2 different cell types, it has been practically impossible to purify goblet cell mucins from airway mucus. ${ }^{44}$ Therefore, the structure of airway goblet cell mucins was initially defined based mainly on cytochemistry in which the secretory granules are stained with various dyes, depending on the degree of acidity of the mucins. ${ }^{45,46}$ Such studies indicated that goblet cell mucins contain neutral, sialylated, and sulphated sugars, and that the distribution of these mucins varies greatly depending on animal species. Biochemical characterization of the epithelial mucin was made possible only after successful isolation and culturing of these cells. ${ }^{43}$ Secretory mucins are stored in secretory granules and released at the apical surface in response to mucin secretagogues, while membranetethered mucins are integrated into the cell membrane. ${ }^{47}$

Our results show that CsA causes a significant decrease in both acid and neutral mucin production from goblet cells and thus could potentially play a significant contributory role in the complex mechanisms of mucociliary transport and clearance. Further studies are necessary to investigate the exact cellular mechanisms of CsA action on goblet cells, either on mucin gene expression or on ionic channels of the apical membrane.

\section{RESUMO}

Pazetti R, Pego-Fernandes PM, Ranzani OT, Parra ER, Lorenzi-Filho G, Jatene FB. Ciclosporina A reduz a secreção de muco das vias aéreas e o transporte mucociliar de ratos. Clinics. 2007;62(3):345-52.

OBJETIVO: Avaliar os efeitos da ciclosporina A sobre a produção de muco das células caliciformes e sobre o transporte mucociliar in situ de ratos.

MÉTODOS: Vinte e um ratos machos Wistar foram distribuídos em três grupos: Controle $(n=5)$, Salina $(n=8)$ e Ciclosporina A $(n=8)$. Após 30 dias de terapia, os ratos foram mortos e os pulmões removidos da cavidade torácica. Amostras de muco foram coletadas e a medida da transportabilidade in vitro foi realizada através de um modelo de palato de rã. A velocidade do transporte mucociliar foi medida através da observação direta do deslocamento de partículas aderidas ao muco do epitélio ciliado brônquico. Por fim, efetuamos a quantificação das mucinas estocadas nas células caliciformes do epitélio respiratório.

RESULTADOS: O valor médio da concentração sangüínea da ciclosporina no momento do sacrifício dos ratos foi de
$1.246,57 \pm 563,88 \mathrm{ng} / \mathrm{ml}$. A transportabilidade do muco in vitro foi estatisticamente menor $(p<0.001)$ no grupo tratado com ciclosporina. Da mesma forma, houve um decréscimo na velocidade de transporte mucociliar nos animais imunossuprimidos em relação aos que receberam o placebo $(p=0.02)$. Houve diminuição significativa na quantidade de muco ácido $(\mathrm{p}=0,01)$ e neutro $(\mathrm{p}=0,02)$ produzidos pelas células caliciformes nos animais tratados com ciclosporina. A correlação entre a porcentagem de muco e a transportabilidade in vitro foi positiva e significante $(r=0.706, p<0.001)$, assim como entre a porcentagem do muco e o transporte mucociliar in situ $(\mathrm{r}$ $=0.688, \mathrm{p}=0.001$ ).

CONCLUSÃO: O presente estudo mostra que a ciclosporina A age no sistema mucociliar causando um sério prejuízo através da redução na produção de muco ácido e neutro pelas células caliciformes como também a diminuição da velocidade de transporte mucociliar in situ e a transportabilidade do muco in vitro.

UNITERMOS: Ciclosporina, Transporte mucociliar, Célula caliciforme, Mucinas. 


\section{REFERENCES}

1. Sadé J, Eliezer N, Silberberg A, Nevo AC: The role of mucus in transport by cilia. Am Rev Respir Dis. 1970;102:48-52.

2. Houtmeyers E, Gosselink R, Gayan-Ramirez G, Decramer M. Regulation of mucociliary clearance in health and disease. Eur Respir J. 1999;13:1177-88

3. Speich R, van der Bij W. Epidemiology and management of infections after lung transplantation. Clin Infect Dis. 2001;33:S58-65.

4. Kahan BD, Welsh M, Rutzky LP. Challenges in cyclosporine therapy: the role of therapeutic monitoring by area under the curve monitoring Ther Drug Monit. 1995;17:621-4.

5. Ruhlmann A, Nordheim A. Effects of the immunosuppressive drugs CsA and FK506 on intracellular signaling and gene regulation. Immunobiology. 1997;198:192-206.

6. Vaden SL. Cyclosporine and tacrolimus. Semin Vet Med Surg (Small Anim). 1997;12:161-6

7. King MB, Jessurun J, Savik SK, Murray JJ, Hertz ML. Cyclosporine reduces development of obliterative bronchiolitis in a murine heterotopic airway model. Transplantation. 1997;63:528-32.

8. Ceyhan BB, Sungur M, Celikel CA, Celikel T. Effect of inhaled cyclosporin on the rat airway: histologic and bronchoalveolar lavage assessment. Respiration. 1998;65:71-8.

9. Wada K, Kaminuma O, Mori A, Nakata A Ogawa K, Kikkawa H, et al IL-5 producing $\mathrm{T}$ cells that induce airway eosinophilia and hyperresponsiveness are suppressed by dexamethasone and cyclosporin A in mice. Int Arch Allergy Immunol. 1998;117:24-7.

10. Winter JB, Groen M, Welling S, van der Logt K, Wildevuur CRH, Prop J. Inadequate antibody response against respiratory viral infection in long-surviving rat lung allografts. Transplantation. 1995;59:1583-9.

11. Mihatsch MJ, Kyo M, Morozumi K, Yamaguchi Y, Nickeleit V, Ryffel B. The side-effects of ciclosporine-A and tacrolimus. Clin Nephrol. 1998;49:356-63

12. Sovcikova A, Tulinska J, Kubova J, Liskova A, Syrova D, Horakova K. Effect of cyclosporin A in Lewis rats in vivo and HeLa cells in vitro. J Appl Toxicol. 2002;22:153-160.

13. Simon N, Morin C, Bruguerolle B, Tillement JP. Effects of trimetazidine on altered functions of rat kidney induced by cyclosporine. Therapie. 2001:56:583-7.

14. Khanna A, Li B, Stenzel KH, Suthanthiran M. Regulation of new DNA synthesis in mammalian cells by cyclosporine. Demonstration of a transforming growth factor beta-dependent mechanism of inhibition of cell growth. Transplantation. 1994;57:577-82.

15. Koskinen PK, Kallio EA, Krebs R, Lemstrom KB. A dose-dependent inhibitory effect of cyclosporine A on obliterative bronchiolitis of rat tracheal allografts. Am J Respir Crit Care Med. 1997;155:303-12.

16. Kano K, Kyo K, Yamada Y, Ito S, Ando T, Arisaka O. Comparison between pre- and posttreatment clinical and renal biopsies in children receiving low dose cyclosporine-A for 2 years for steroid-dependent nephrotic syndrome. Clin Nephrol. 1999;52:19-24.
17. Lacayo NJ, Lum BL, Becton DL, Weinstein H, Ravindranath Y, Chang $\mathrm{MN}$, et al. Pharmacokinetic interactions of cyclosporine with etoposide and mitoxantrone in children with acute myeloid leukemia. Leukemia. 2002;16:920-7.

18. Guide for the care and use of laboratory animals. Institute of laboratory animal resources. National Research Council of the National Academy of Sciences. Washington, D.C. National Academy Press 1996;1-35.

19. Journal of the American Veterinary Medicine Association 2001;218, n.5.

20. King, M. Experimental models for studying mucociliary clearance. Eur Respir J. 1998;11:222-8

21. Puchelle E, Zahm JM, Aug F. Methods of studying mucociliary function. Presse Med. 1988;17:479-84.

22. Rubin BK, Ramirez O, King M. Mucus-depleted frog palate as a model for the study of mucociliary clearance. J Appl Physiol. 1990;69:424-9.

23. Mowry RW. Alcian blue techniques for histochemical study of acidic carbohydrates. J Histochem Cytochem. 1956;4:407. Apud Harkema JR, Plopper CG, Hyde DM, St George JA. Regional differences in quantities of histochemically detectable mucosubstances in nasal, paranasal, and nasopharyngeal epithelium of the bonnet monkey. J Histochem Cytochem. 1987;35:279-86.

24. Rosner B. Fundamentals of Biostatistics. $2^{\text {nd }}$ ed. Boston: PWS Publishers; 1986. p. 584

25. Corsi RCC, Silva ABD, Santos JC, Santos SRCJ, Gemperli R, Ferreira MC. Kinetic disposition of the cyclosporin A after $2.5 \mathrm{mg} / \mathrm{kg} ; 5.0 \mathrm{mg} /$ $\mathrm{kg}$ and $10.0 \mathrm{mg} / \mathrm{kg}$ single dose subcutaneous administration. Experimental study in rats. Rev Hosp Clin Fac Med S Paulo. 1995;50(Suppl):30-4.

26. Atkinson K, Boland J, Bitton K, Biggs J. Blood and tissue distribution of cyclosporine in humans and mice. Transplant Proc. 1983;15:24306.

27. Smith J, Hows J, Gordon-Smith EC. In vitro stability and storage of cyclosporine in human serum and plasma. Transplant Proc. $1983 ; 15: 2422-6$

28. Lemaire M, Jillemont JP. Role of lipoproteins and erythrocytes in the in vitro binding and distribution of cyclosporin A in the blood. J Pharm Pharmacol. 1982;34:715-7.

29. Miraz W, Zink RA, Graf A. Distribution and transfer of cyclosporine among the various human lipoprotein classes. Transplant Proc. $1983 ; 15: 2426-31$

30. Kahan BD, Oates JA, Wood AJ. Cyclosporine in drug therapy. N Engl J Med. 1989;321:1725-8.

31. Ryffel B, Foxwell BM, Mihatsch MJ, Donatsch P, Maurer G. Biologic significance of cyclosporine metabolites. Transplant Proc. 1988;20:57580

32. Wassef R, Cohen Z, Langer B. Pharmacokinetic profiles of cyclosporine in rats. Influence of route of administration and dosage. Transplantation. 1985;40:489-93

33. Lopez-Vidriero MT. Biochemical basis of physical properties of respiratory tract secretions. Eur J Respir Dis. 1987;71:130-5. 
34. King M. Experimental models for studying mucociliary clearance. Eur Respir J. 1998;11:222-8.

35. King M. Relationship between mucus viscoelasticity and ciliary transport in guaran gel/frog palate model system. Biorheology. 1980;17:249-54

36. Puchelle E, Zahm JM, Polu JM. Drug effects on viscoelasticity of mucus. Eur J Respir Dis. 1980; 61:195-208.

37. Lorenzi G, Böhm GM, Guimarães ET, Costa Vaz MA, King M, Saldiva PN. Correlation between rheological properties and in vitro ciliary transport of rat nasal mucus. Biorheology. 1992;29:433-40.

38. Widdicombe JH, Widdicombe JG. Regulation of human airway surface liquid. Respir Physiol. 1995;99:3-12.

39. Macchione M, Guimarães ET, Saldiva PHN, Lorenzi-Filho, G. Methods for studying respiratory mucus and mucus clearance. Braz J Med Biol Res. 1995;28:1347-55.

40. Boucher RC. New concepts of the pathogenesis of cystic fibrosis lung disease. Eur Respir J. 2004;23:146-58.

41. Matsui H, Grubb BR, Tarran R, Randell SH, Gatzy JT, Davis CW, et al. Evidence for periciliary liquid layer depletion, not abnormal ion composition, in the pathogenesis of cystic fibrosis airways disease. Cell. 1998;95:1005-15.
42. Mall M, Grubb BR, Harkema JR, O'Neal WK, and Boucher RC. Increased airway epithelial $\mathrm{Na}^{+}$absorption produces cystic fibrosis-like lung disease in mice. Nature Med. 2004;10:487-93.

43. Kim KC, McCracken K, Shin CY, Jo MJ, Lee CJ, Ko KH. Airway goblet cell mucin: its structure and regulation of secretion. Eur Respir J. 1997;10:2644-9.

44. Rose MC. Characterization of human tracheobronchial mucin glycoproteins. In: Ginsburg V, editor. Methods in enzymology. New York: Academic; 1989. vol. 179, p. 3-17. Apud Rose MC and Voynow JA. Respiratory tract mucin genes and mucin glycoproteins in health and disease. Physiol Rev. 2006;86:245-78.

45. Spicer SS, Mochizuki I, Setser ME, Martinez JR. Complex carbohydrates of rat tracheobronchial surface epithelium visualized ultrastructurally. Am J Anat. 1980;158:93-109.

46. Plopper CG, St. George JA, Nishio SJ, Etchison JR, Nettesheim P. Carbohydrate cytochemistry of tracheobronchial airway epithelium of the rabbit. J Histochem Cytochem. 1984;32:209-18.

47. Rose MC. Mucins: structure, function, and role in pulmonary diseases. Am J Physiol Lung Cell Mol Physiol. 1992;263:L413-L429. 